\title{
A Tribute to William Burton Preston, 1937-2013
}

\author{
Robert E. Wrigley ${ }^{1}$, Terry D. Galloway ${ }^{2}$, James R. DunCan ${ }^{3}$, and Francis R. Cook ${ }^{4,5}$ \\ ${ }^{1} 505$ Boreham Boulevard, Winnipeg, Manitoba R3P 0K2 Canada \\ ${ }^{2}$ Professor Emeritus, Department of Entomology, Faculty of Agricultural and Food Sciences, University of Manitoba, Winnipeg, \\ Manitoba R3T 2N2 Canada \\ ${ }^{3}$ Wildlife and Fisheries Branch, Manitoba Department of Sustainable Development, P.O. Box 24, 200 Saulteaux Crescent, Win- \\ nipeg, Manitoba R3J 3W3 Canada \\ ${ }^{4}$ Curator Emeritus, Research Associate, Canadian Museum of Nature, P.O. Box 3443, Station D, Ottawa, Ontario K1P 6P4 Canada \\ ${ }^{5}$ Corresponding author: frcook@ripnet.com
}

Wrigley, Robert E., Terry D. Galloway, James R. Duncan, and Francis R. Cook. 2016. A tribute to William Burton Preston, 19372013. Canadian Field-Naturalist 130(4): 355-358.

William Burton Preston (Figure 1), 76, passed away at St. Boniface Hospital in Winnipeg, Manitoba, 11 October 2013 after an extended struggle with kidney failure which necessitated regular dialysis. He was born in Penticton, British Columbia, on 6 March 1937, to Earl and Kathleen Preston.

Bill was an outstanding example of a dedicated naturalist who effectively combined academic credentials with his field experience and communication skills to reach out and share his own fascination with nature with the public. As pointed out in in an earlier tribute (2014, which has contributed large portions of the text here, see Acknowledgments), Bill grew up happily exploring the desert, grassland, and forests of the Okanagan Valley, and there developed his love of nature and interest in rattlesnakes and the insect fauna.

He obtained a B.Sc. and M.Sc. at the University of British Columbia in wildlife management. His M.Sc. thesis was a study of the facial pits of the Northern Pacific Rattlesnake (Crotalus viridis oreganus). After graduating, Bill married Willetta, and the couple moved south to Norman, Oklahoma for Bill to do a Ph.D. in Zoology comparing the ecology of two species of water snakes. They also studied the rich insect fauna of the region and in addition, explored many parts of the southern United States, Mexico, and St. Lucia.

Returning to Canada in 1969, Bill accepted the position of Curator of Reptiles, Amphibians and Fishes at the newly opened Manitoba Museum of Man and Nature in Winnipeg, where he remained for 28 years. His outstanding Amphibians and Reptiles of Manitoba was published in 1982 by the Museum. Bill loved field work and was elated to discover the first Manitoba records of the Great Plains Toad (Bufo cognatus) and a species of ant. His interest in amphibians and reptiles never waned but was eventually secondary to entomology for which he amassed an extensive insect collection from the time he was a boy. He co-authored The Butter-

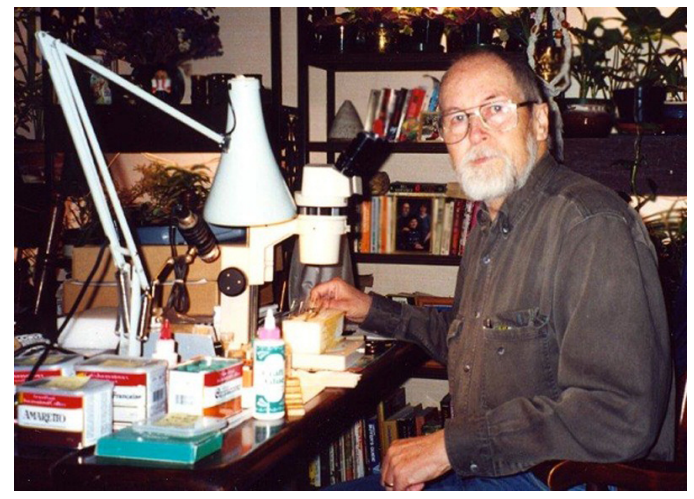

FIgURE 1. Bill in the Preston Winnipeg home - the insects tended to take over the house - taken in the late $1990 \mathrm{~s}$ soon after he had retired and was coming to terms with his medical issues. Photo: Willetta Preston.

flies of Manitoba and contributed to the Encyclopedia of Manitoba, as well as numerous journal articles.

F.R.C. first met Bill in 1963 at the Annual Meeting of American Ichthyologists and Herpetologists in Vancouver, on Bill and Willetta's return from their honeymoon in San Francisco. Bill had just finished the research for his M.Sc. and, after the meetings, offered to be a guide to see habitats and species of amphibians and reptiles in the Okanagan region. A friendship was forged that lasted a lifetime. In 1971, they both attended the American Society of Ichthyologists and Herpetologists meetings at Los Angeles and on a memorable field trip to the desert areas to the east, Bill demonstrated the proper handling of poisonous snakes in collecting a sidewinder at night on the road. Years later when F.R.C.'s wife, Joyce, discovered her calling in entomology, Bill never failed to mention when he had seen one of her papers whenever they met. He gained examples of spiders collected on a visit to F.R.C.'s farm on a stopover in Ottawa 
years ago, as Bill never missed an opportunity to add to his collections.

Willetta has provided F.R.C. with some reflections (personal communications, 12 and 13 November 2016):

"I do remember the Los Angeles meeting field trip... catching the snake and big water beetles on our night drive. The snake returned to Canada in his suitcase tied in a snake bag inside one of his cigar boxes he used for insects. Before the days of $x$-raying everything. We went to Ichs and Herps meeting in Costa Rica in the early 70's and while he was interested in all the herps he also collected insects which were much more common than the herps. Ken Stewart and Pat Gregory were there too and we ate at McD's not for the food as much as for the insects that came to the lights. He would walk along the streets picking up things or taking them off store windows. He took his net into an open air bar and picked a large insect off the wall above the bar with the bartenders ok after much miming and net waving. Earlier that day the bus had dropped us out of town a bit and we walked back collecting along the way. The recent earthquake there had taken out the power in most of the town and volcanic bombs had destroyed the church windows. We found a store that sold flashlights and they soon had a run on them when the rest of the group saw them. There was much interest from the locals in our activities and heard "gringos" and "ranas" mentioned . Likely as well our Spanish was spotty. He always had an insect net with him and I was asked by one of the women in the group why an entomologist was on the I and $\mathrm{H}$ trip. His version of multitasking. ... We went to Australia to spider meetings stopping at Fiji on our way back, to Trinidad and Tobago for spider meetings, to Barbados, Haiti and Hawaii and he went to the Dominican Republic and Colorado on butterfly trips. We both went to Ecuador on a butterfly trip where we went into a remote field camp by dugout canoes. ... We enjoyed our travels but the Okanagan was always home and we owned the family farm for 20 years after his dad died intending to retire there. It was a very difficult decision to sell it but didn't make sense to move there for family and medical reasons and the fact the bulk of his professional life had been here [Winnipeg]. When we went there to ready the house for sale we went to his master's research collecting area on the mountain and he climbed up to the top using all his energy. Again I worried and wondered but he yelled down all pleased with himself from the top. Guess you have to live not just exist. We went near there again but no more talk of climbing. He was very upset with the encroachment of the vineyards in the valley he roamed as a boy and in some ways made the decision to sell easier for him. He refused to drink Okanagan wine and many a server got a lecture on why. The family still mentions it when we order wine when we are out. My uncle owned a pool at his home in Westbank near Kelowna and Bill was always willing to skim the pool not just to help but he fished some great specimens out if it. He would wander on the hill above the pool in uncle's orchard with his camera and bug net usually followed by whatever kids were there at the time.

We did do a tour of Spain and Morocco in 2003 (Africa was one of the items on his bucket list) which we thoroughly enjoyed but by then his energy levels were lim- ited so he wasn't able to do much collecting. However he did take lots of film and edited a nice movie from it ... In Australia we went to the butterfly garden in Kuranda where they toured him through the breeding areas a beautiful place. He loved Australia and was fascinated with all the new species of everything. We also went to the open air market where he bought a didgeridoo. The seller gave him a lesson and he got pretty good on it. On our way to Fiji we had a day's layover in Brisbane so we stored our luggage in airport lockers and went into town. It was too big to fit the lockers so went to town with us. We dropped off his insects at the Queensland museum where they would arrange to send them to him and revisited a neat bookstore he had found when we were there earlier at the meetings. He walked up to a salesman and asked what they had in sheet music for the didgeridoo. He looked a little taken aback and then said they didn't have much call for it. They both had a good laugh. One of a kind for sure. I made the best decision of my life when we were married and have enjoyed a very rich life with him."

In Winnipeg, Bill walked frequently down to the Red River behind the Manitoba Museum during his lunch break and faithfully recorded notes on the appearance and habits of butterflies. At the Museum in the 1970s (Figure 2), Bill contributed to a number of permanent-gallery exhibits on insects, amphibians, reptiles and fishes, and participated in a nationally travelling exhibit on "Collecting Manitoba's Natural Heritage". His giant model of a female mosquito is a masterpiece, exact is every detail.

He never lost his "little boy" excitement about learning new things regarding the natural world, and he just had to discuss these observations with his Museum colleagues. In fact, it was impossible to walk past the open door of his office without being invited in for a lengthy conversation. Bill was also notorious for his quirky sense of humour, and often he could barely complete a joke without losing his voice as he broke out in laughter. He loved showing youngsters the many critters in his laboratory, ranging from a Hognose Snake (Heterodon nasicus) to a giant, one-eyed Snapping Turtle (Chelydra serpentina) he had rescued from the Assiniboine River. Bill had the well-earned respect of his many friends and colleagues due to his broad knowledge, developed over his career at the Museum. Bill was always generous with his time and expertise, and often helped friends and students with troublesome identifications of the species he knew best.

Bill was an active participant in the Entomological Society of Manitoba Youth Encouragement and Public Education Committee, when it was revamped under the president-ship of Ron Sinha in 1973. The group organized numerous field trips and workshops in the ensuing years, to La Barrière Park, Sandilands Provincial Forest, and to the newly developing outdoor education facility at Fort Whyte.

For a number of consecutive years, the Youth Encouragement Committee conducted a week-long display on insects at Polo Park Shopping Mall, and later at the 


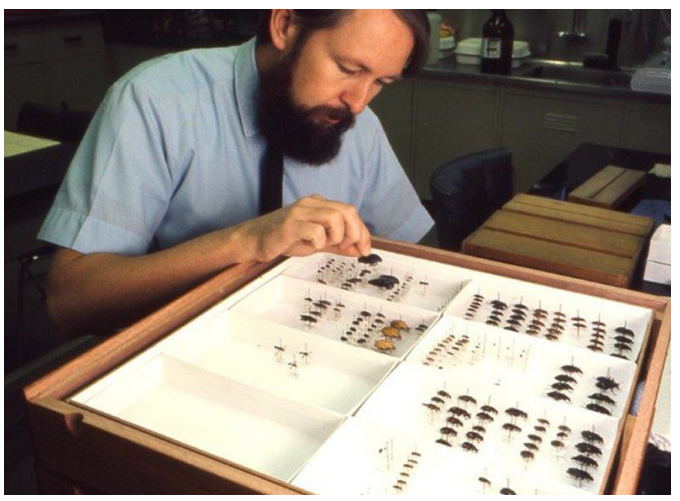

FIGURE 2. Bill in his lab at the museum in 1972. Image (CThe Manitoba Museum, Winnipeg, Manitoba. Photo: Robert Taylor.

newly opened St. Vital Mall. There were all manners of insects, alive and dead on offer to the public. Bill was the only person who always attended all day every day of the exhibit. He loved to talk about insects, and there was hardly a better opportunity for non-stop conversation than at the entomology display. He could never understand the concern of the Polo Park manager when someone had placed a drinking straw to breach the petroleum jelly barrier that was meant to contain the Thatching Ant (Formica obscuripes) colony. Many of the ants had gone walkabout in the night and were found by disgruntled shop keepers the next morning. Bill just couldn't see the problem: to him they were harmless ants.

Bill belonged to a number of associations including the Entomological Society of Canada, The Entomological Society of Manitoba, Manitoba Naturalists, Winnipeg Amateur Movie Makers, and the Rock and Mineral Society. T.D.G. commented that he didn't think he could emphasize enough Bill's contributions to the Youth Encouragement and Public Education Committee of the Entomological Society of Manitoba (ESM), notably in the early to the mid-1970s. The President of the ESM essentially turned over responsibility for this committee's activities to the graduate students in the Department of Entomology. T.D.G. was the first student to chair the committee in 1973-1974. Bill was the one 'adult' member of the ESM who was very enthusiastic about activities of the committee, and he served in official and unofficial capacities on it for all the years T.D.G. was a member.

ESM hosted many field trips to La Barrière Park, Sandilands Provincial Forest, and Fort Whyte Centre, to name a few, and Bill shared in knowledge and expertise with one and all. At one point, the Youth Encouragement Committee had a mailing list of more than 100 kids who were contacted for each event. The participants even chose a name for their group, "The ESM Young Entomologists", and produced a logo and pin. Bill was part and parcel of all of this.
His photography expertise was also something highly valued by his entomological colleagues. Bill's photos have been widely published, and he gave many talks to the public and to arthropod enthusiasts. He was always generous with his knowledge about photographic techniques, and he encouraged many aspiring macrophotographers. He also organized the photo salon for the Entomological Society of Canada. This was a tremendous amount of work, but he loved receiving and going through all the entries.

He was a member of several government committees such as the Manitoba Endangered Species Advisory Committee from 24 June 1988 to the time of his death, and attended meetings regarding the snake pits at Narcisse. During these years, he was instrumental in providing advice to the Minister on the listing of species as Endangered or Threatened under the Manitoba Endangered Species Act. Bill also helped us with the assessment of the NatureServe conservation S-Ranks for various invertebrate taxa (mussels, butterflies, tiger beetles, etc.) in the formative years of the Manitoba Conservation Data Centre, and more recently for the federal-provincial-territorial General Status Ranks of Wild Species program. J.R.D. stressed that he generously assisted the province of Manitoba in better understanding the conservation status of a large slice of the diversity of wild animals and plants on both informal and formal (legislative) programs. He also made considerable contributions to the Manitoba volunteer dragonfly surveys which documented 11 species new to Manitoba. No matter the occasion, Bill always worked very hard while also infusing the efforts with a sense of humour despite the many personal health challenges he faced. His contagious enthusiasm and passion for wild species and nature will be greatly missed.

Bill twice received the West Kootenay Rod and Gun Club Bursary Award while attending the University of British Columbia; later he received the Criddle Award for excellence in amateur entomology, presented by the Entomological Society of Canada in 1994 and Blue Racer Award presented by the Canadian Amphibian and Reptile Conservation Network for long-standing contributions to the research and conservation of amphibians and reptiles in Canada in 2002. Upon his death, Bill was added to the list of Memorable Manitobans by the Manitoba Historical Society for 2013.

In later years, Bill's health deteriorated to the point where he could no longer participate in field activities but, with the loving support of Willetta, he maintained a positive attitude about life and his passion for nature to the end of his days.

At the time of his death, Bill was working on projects about tiger beetles, ants, the Okanagan Valley (Figure 3 ), and an autobiography for his family. He had a pretty well completed manuscript on Manitoba tiger beetles and was working on one on ants and another on the Okanagan of his youth compared to the changes now. After his death, his entomology collection of 24,364 


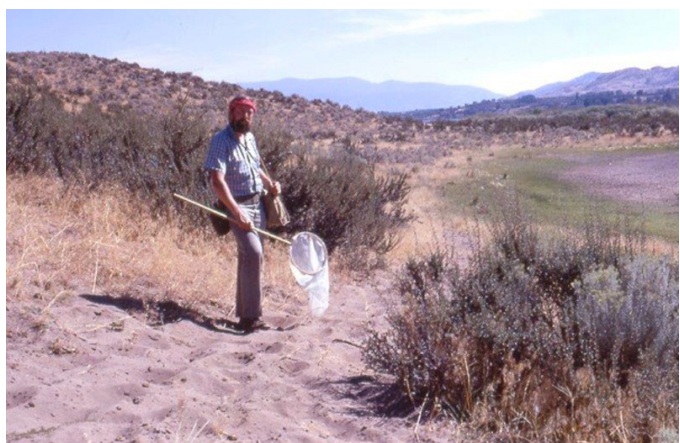

FIGURE 3. Bill collecting in the Okanagan in 1974, his version of Eden was roaming those hills. Photo: Willetta Preston.

specimens was donated by his estate to the $\mathrm{B}$. Wallis/R. E. Roughley Museum of Entomology at the University of Manitoba. T.D.G. and technician Dave Holder filled the back of a half-ton truck with it from the Preston home to transport it to the university one cold, wintry Winnipeg afternoon.

Bill is survived by his wife of 50 years, Willetta; his son David (Jill), their children Jessica and Declan of Calgary; his daughter Kathi (Rob) their children Jordan (Jessica), Steven (Crystal), and Trevor; and daughter Carmen (Dave), their children Shayla and Evan as well as four great-grandchildren Stormii, Konnor, Steven, and Kailee; his brother Tom, sisters Marilyn (Fred) and Joanne (Mark); sisters-in-law Gwen (Mike) and Gretta; as well as a number of nieces, nephews, cousins.

\section{Acknowledgements}

Primary information at Bill's passing appeared in the Winnipeg Free Press 19 October 2013. Bill's wife, Willetta, and daughter Carmen, provided this and other records, including photographs, from Bill's files. And we are indebted to both for personal recollections which included Carmen's on what it was like growing up in a herpetologist/entomologists home. Thanks are due for comments from Randy Mooi and to Nancy Anderson for help with granting permission for one of the photographs, both at The Manitoba Museum. Much of the text here is drawn from the earlier tribute by R. Wrigley and T. Galloway; William Burton Preston (1937-2013 2014) - One of a Kind. The Entomological Society of Manitoba Newsletter. 40(2): 4-5 (Fall/Winter 20132014) and Bulletin of the Entomological Society of Canada 46(1): 38-39 (2014) with supplementary additions by the authors.

\section{Bibliography of William Burton Preston}

Preston, W. B. 1964. The importance of the facial pit of the Northern Pacific Rattlesnake (Crotalus viridis oreganus) under natural conditions in southern British Columbia. M.Sc. thesis, University of British Columbia, Vancouver, British Columbia, Canada. [Supervisor: Dr. Ian McTaggart Cowan]

Preston, W. B. 1970. The comparative ecology of two water snakes, Natrix rhombifera and Natrix erythrogaster, in Oklahoma. Ph.D. dissertation, University of Oklahoma, Norman, Oklahoma, USA. [Supervisor: Dr. Charles C. Carpenter]

Preston, W. B. 1971. Infrared receptors in snakes. Manitoba Nature Magazine 12: 20-23.

Preston, W. B. 1971. Snakes. Manitoba Nature Magazine 12: 26-29. (with Bill's photos of four species)

Preston, W. B. 1972. Snake hibernacula. Manitoba Nature Magazine 13: 12-13.

Preston, W. B. 1972. Turtles, terrapins and tortoises. Manitoba Nature Magazine 13: 16-19.

Preston, W. B. 1973. Frogs and toads. Manitoba Nature Magazine 14: 27-30. (with Bill's beautiful photos of eight species)

Preston, W. B. 1974. The flat flea of the beaver. Manitoba Nature Magazine 15: 24-25.

Preston, W. B. 1975. Band-winged grasshoppers. Manitoba Nature Magazine 16: 14-17. (with Bill's cover photo of Trimerotropis agrestis, camouflaged on sand)

Galloway, T. D., and W. B. Preston. 1982. Distribution and occurrence of yellow jackets (Hymenoptera: Vespidae: Vespula spp.) in Manitoba. The Canadian Entomologist 114: 79-80

Preston, W. B. 1982. Amphibians and Reptiles of Manitoba. Manitoba Museum of Man and Nature, Winnipeg, Manitoba, Canada.

Preston, W. B. 1986: The Great Plains Toad, Bufo cognatus, an addition to the herpetofauna of Manitoba. Canadian Field-Naturalist 100: 119-120.

Preston, W. B. 2009. The distribution of the Plains Spadefoot, Spea bombifrons, in relation to soil type in southwestern Manitoba. Canadian Field-Naturalist 123: 107-111.

Preston, W. B., and D. R. M. Hatch. 1986. The Plains Spadefoot, Scaphiopus bombifrons, in Manitoba. Canadian FieldNaturalist 100: 123-125.

Klassen, P., A. R. Westwood, W. B. Preston, and W. B. McKillop. 1989. The Butterflies of Manitoba. Manitoba Museum of Man and Nature, Winnipeg, Manitoba, Canada.

Wrigley, R., and W. B. Preston. 2007. Ants. Pages 19-20 in The Encyclopedia of Manitoba. Edited by Ingeborg Boyens; Zoological Editor R. Wrigley. Great Plains Publishing, Winnipeg, Manitoba, Canada.

Wrigley, R., and W. B. Preston. 2007. Turtles. Pages 693-694 in The Encyclopedia of Manitoba. Edited by Ingeborg Boyens; Zoological Editor R. Wrigley. Great Plains Publishing, Winnipeg, Manitoba, Canada.

Received 13 November 2016

Accepted 15 December 2016 